\title{
Psychological State and Behavioural Profiles of Freshman Enrolled in College and University In- structional Physical Activity Programmes under Different Policy Conditions
}

\author{
Moosong Kim ${ }^{1}$, Bradley J. Cardinal ${ }^{2}$
}

\begin{abstract}
Affiliations: 'Northeastern State University, College of Education, Department of Health and Kinesiology, Tahlequah, Oklahoma, United States, ${ }^{2}$ Oregon State University, College of Public Health and Human Science, School of Biological and Population Health Sciences, Kinesiology Program, Corvallis, Oregon, United States
\end{abstract}

Correspondence: M. Kim, Northeastern State University, College of Education, Department of Health and Kinesiology, Tahlequah, OK 74464, United States, e-mail: kimm@nsuok.edu

ABSTRACT Between late adolescence and early adulthood, people experience a precipitous decline in their participation in physical activity. Those attending college or university are often presented with opportunities to partake in physical activity, sometimes under compulsory conditions and sometimes under elective conditions. This study examined the psychological and behavioural characteristics of freshman students under these two separate conditions. The main finding was that students under the elective condition felt more competent and motivated compared to those in the compulsory condition. They were also more physically active. When offered as electives, tertiary level physical activity education courses may be limited in reach, primarily attracting those who would likely be physically active without any such coursework.

KEY WORDS competence, compulsory, elective, exercise, higher education, motivation, physical activity, requirement

$@ M J S S M o n t e n e g r o$

PSYCHOLOGICAL AND BEHAVIOURAL PROFILES OF FRESHMEN

http://mjssm.me/?sekcija=article\&artid=177

\section{Introduction}

Regularly engaging in physical activity is an essential individual health behaviour and a significant public health priority (U.S. Department of Health and Human Services (USDHHS), 2008). However, during the transition from late adolescence to early adulthood, there is a precipitous decline in physical activity participation (Blackwell \& Clarke, 2018; Center for Disease Control and Prevention (CDC), 2016; Li, Cardinal, \& Settersten, 2009; Zick, Smith, Brown, Fan, \& Kowaleski, 2007). This is apparent on college and university campuses, as only half of college/university students meet physical activity recommendations (i.e., $>150$ minutes of moderate or $>75$ minutes of vigorous intensity physical activity per week or the equivalent combination of the two) (American College Health Association (ACHA), 2018). As such, during the transitional period between secondary and tertiary education, colleges and universities have been encouraged to do more to support the physical activity behaviours of their students (Cardinal, 2017; Corbin \& Cardinal, 2008; Curry, Jenkins, \& Weatherford, 2015; Sparling, 2003).

Some colleges and universities seek to accomplish this by offering their students a range of physical activity education (PAE) courses in either an elective or a required (i.e., compulsory) format (Beaudoin, Parker, Tiemersma, \& Lewis, 2018; Cardinal, Sorensen, \& Cardinal, 2012; Hensley, 2000). Within academic units, these have been labelled, "College and University Instructional Physical Activity Programmes" (C/UIPAP; a.k.a. basic instruction programmes, physical activity classes, service programmes; Cardinal, 2017), though other organizational arrangements, names, and purposes have been proposed (You, Craig, \& Oh, 2018). Such courses have been positively associated with college and university students' physical activity attitudes, behaviours, knowledge, and skills during

Received: January 212019 | Accepted after revision: March 062019 | First published online: September 012019

(C) 2019 by the author(s). License MSA, Podgorica, Montenegro. This article is an open access article distributed under the terms and conditions of the Creative Commons Attribution (CC BY).

Conflict of interest: None declared. 
the college/university years and beyond (Adams \& Brynteson, 1992; Brynteson \& Adams, 1993; Casebolt, Chiang, Melton, \& Russell, 2017; Pearman et al., 1997; Sparling \& Snow, 2002; Williams, Greene, Fry, Neuberger, \& Satinsky, 2018; Woekel, Ebbeck, Concepcion, Readdy, Li, Lee, \& Cardinal, 2013).

Despite this, not all institutions support C/UIPAP. When they do, they are more likely to be supported as electives versus requirements in the curriculum (Cardinal et al., 2012; Hensley, 2000). For example, Cardinal et al. (2012) found that only $39.6 \%$ of higher institutions in the U.S. required their students to experience PAE as a core component of their baccalaureate degree education. In subsequent work, Cardinal (2017) reported that only an estimated $3.43 \%$ of college and university students in the United States participate in C/UIPAP. Given their potential value in promoting student health and wellbeing, widespread reach within the American higher education system, and contributions in helping achieve other institutional goals such as academic success (Casebolt et al., 2017), interdisciplinary studies (Cardinal, 2016), internationalization efforts (Yan \& Cardinal, 2013), and student retention (Kim \& Cardinal, 2016), understanding how different policy arrangements might affect students could help inform policy decisions and their ramifications. For example, Ansuini (2001) reported that within three years of dropping their requirement, one university observed negative trends in the exercise and nutritional behaviours of their students.

Whether the elective or required arrangement is in the best interest of students has been debated for at least a century (Mak \& Cheung, 2018; Sargent, 1908). The timing of any such requirement has received research attention, too, with the recommendation that it might best serve the interests and needs of the students during their freshman year versus just prior to graduating (Sallis et al., 1999).

Of course, policy decisions alone are not panaceas or cures in solving the problems associated with physical inactivity (Sallis, 2018). On the basis of the social-ecological model (Stokols, 1992), an individual's behavioural choices are affected through the dynamic interplay between individual characteristics (e.g., self-efficacy, self-determined motivation, knowledge) and environmental features (e.g., campus fitness facilities, college and university PAE policy). This proposition is in agreement with other leading psychological theorists of the 20th century (Gill, 2009). For example, Lewin (1936) proposed that behaviour is a function of the person and her/his environment, expressed in a formula as $\mathrm{B}=\mathrm{f}(\mathrm{P}, \mathrm{E})$. Bandura (1986) also recognized the reciprocal, triadic relationship among person, environment, and behaviour in his social learning/cognitive theory. In the context of tertiary PAE settings, an institution's PAE policy (e.g., elective versus required) would be hypothesized to influence college and university freshmen participation in C/UIPAP.

Individual characteristics (e.g., gender, self-efficacy, self-determination) also may differentially affect physical activity behaviour and participation in C/UIPAP. For example, Doerkesen, Umstattd, and McAuley (2009) found that self-efficacy and physical activity goals are factors predicting freshmen engagement in vigorous physical activity. Different types of motivation also appear to affect students' participation in C/UIPAP. While intrinsic motivation (e.g., enjoyment, fun) is associated with students' sport participation (e.g., basketball, soccer), extrinsic motivation (e.g., appearance, weight management) is associated with fitness-enhancing exercise classes (Kilpatrick, Herbert, \& Bartholomew, 2005; Kim \& Cardinal, 2016, Leenders, Sherman, \& Ward, 2003). Furthermore, gender is another predictor that affects college and university students' participation in C/UIPAP (Kim \& Cardinal, 2017). Specifically, females tend to enrol in fitness classes more so than do males (Lackman, Smith, \& McNeill, 2015; Weinfeldt \& Visek, 2009).

In an attempt to elucidate this situation, the aims of this study were to: (1) determine entering university freshman's physical activity motivation, competence, and physical activity levels at institutions that had different PAE policies (i.e., a required versus an elective PAE policy), and (2) to examine how individual characteristics (e.g., competence, gender, motivation) and institutional PAE policies were associated with freshman's enrolment in C/ UIPAP. Entering freshmen allow for a unique glimpse into the potential effect of institutional policy, as the students have yet to be socialized into their new environment. That is, they very likely enrolled in their courses well before the term began; therefore, their behaviours, psychological dispositions, and course choices are indicative of their distinct interests under the two different policy arrangements (i.e., elective or required).

\section{Methods}

\section{Participants and Setting}

University students enrolled in PAE courses at two universities were recruited for this study. Both institutions were located in the Pacific Northwest region of the United States and are classified as "R1: Doctoral Universities - Highest research activity". Given their geographical proximity, they have nearly identical seasons, topography, and weather.

Identical recruitment strategies were employed at each university, which occurred during the first week of the students' first term of enrolment of their freshman year. For the recruitment, the directors of each university's C/ UIPAP were contacted. The directors agreed to distribute an online Uniform Resource Locator (URL) that took potential study participants to a Qualtrics (Provo, UT, USA) survey that was created for the purposes of data collection.

All study participants $(\mathrm{N}=226)$ provided their informed consent in accordance with the authors' Institutional Review Board and agreed to participate in the study. The significant distinction between the two institutions was that at one of the universities the students were required to complete a PAE course in order to graduate, whereas at 
the other they were not; in other words at the latter university, the students enrolled in PAE courses on an elective basis.

\section{Measures}

Participants completed the online survey comprised of 32 items. The online survey had four sections: a) demographic variables, b) students' motivation toward physical activity, c) students' perceived competence toward physical activity, and d) a 1-week recall of their past week's physical activity behaviour. Participants were asked to provide information about their age, gender, height, weight, race, and type of C/UIPAP they were enrolled in (e.g., dance, fitness, lifetime sports, mind-body, outdoor sports, or team sports). The C/UIPAP courses were classified into these categories using the same classification scheme that has been used in previous research (Barney, Pleban, Wilkinson, \& Prusak, 2015; Hensley, 2000).

The Behavioral Regulation in Exercise Questionnaire (BREQ-2; Markland \& Tobin, 2004) was used to measure the participants' self-determined motivation. The BREQ-2 measures five different types of motivation (i.e., amotivation, external regulation, introjected regulation, identified regulation, and intrinsic motivation). An example intrinsic motivation item is, "I enjoy my physical activity". Response options were displayed using a Likert scale format ranging from 1 (i.e., "do not agree at all") to 7 (i.e., "very strongly agree"). The perceived competence subscale of the Intrinsic Motivation Inventory (McAuley, Duncan, \& Tammen, 1989) was used to assess the participants' perceived competence. A sample item is, "I am pretty skilled at physical activity". Response options were displayed using a Likert scale format ranging from 1 (i.e., "do not agree at all") to 7 (i.e., "very strongly agree"). The Weekly Leisure Time Exercise Questionnaire (WLTEQ; Godin \& Shephard, 1985) was used to measure the participants' recalled physical activity behaviour. The WLTEQ contains three questions assessing the frequency of 15 minutes or longer bouts of mild (e.g., easy walking), moderate (e.g., fast walking and easy cycling), or vigorous (e.g., swimming and running) physical activity during the previous seven days. Weekly exercise METS (i.e., metabolic equivalent units) were calculated by multiplying the frequencies given for mild, moderate, and vigorous by 3,5 , and 9 , respectively, and then summing the results.

\section{Data Analysis}

Descriptive statistics were used to summarize the participants' enrolment in the C/UIPAP course types. A oneway (required vs elective) MANOVA was used to examine whether those who were required to take PAE courses and those who elected to take PAE courses differed on motivation, competence, and/or physical activity behaviour. Furthermore, binary logistic regression was employed to determine whether individual characteristics (i.e., gender, self-determined motivation, competence, and weekly exercise METs) and PAE policies (i.e., a required vs an elective PAE policy) predicted freshman student's enrolments in C/UIPAP. Data were analysed using the IBM Statistical Package for the Social Sciences (SPSS) 22 (Armonk, NY, USA) software.

\section{Results}

Internal consistency, descriptive statistics, and correlation matrix

Table 1 presents the internal consistency values for the psychological measures used in the present study, all of which were acceptable (i.e., Cronbach alpha values ranging from .76 to .91). The Cronbach alpha for the behavioural measure employed in this study (i.e., WLTEQ) was .69. Table 1 also provides descriptive statistics for each variable and a correlation matrix for the various measures used in the study.

TABLE 1 Descriptive statistics, correlations, and reliability among variables $(\mathrm{N}=226)$

\begin{tabular}{|c|c|c|c|c|c|c|c|c|c|c|c|c|}
\hline & & & & & & & & & \multicolumn{2}{|c|}{ A required PAE } & \multicolumn{2}{|c|}{ An elective PAE } \\
\hline & & & & & & & & & $\begin{array}{l}\text { Female } \\
(\mathrm{N}=\mathbf{8 8})\end{array}$ & $\begin{array}{c}\text { Male } \\
(\mathrm{N}=29)\end{array}$ & $\begin{array}{l}\text { Female } \\
(\mathrm{N}=89)\end{array}$ & $\begin{array}{r}\text { Male } \\
(\mathrm{N}=20\end{array}$ \\
\hline Variables & 1 & 2 & 3 & 4 & 5 & 6 & 7 & $a$ & $\begin{array}{c}M \\
\text { (SD) }\end{array}$ & $\begin{array}{c}M \\
\text { (SD) }\end{array}$ & $\begin{array}{c}M \\
\text { (SD) }\end{array}$ & $\begin{array}{c}M \\
\text { (SD) }\end{array}$ \\
\hline AM & 1.0 & & & & & & & .798 & $\begin{array}{l}1.74 \\
(.92)\end{array}$ & $\begin{array}{l}1.67 \\
(.76)\end{array}$ & $\begin{array}{l}1.47 \\
(.68)\end{array}$ & $\begin{array}{l}1.46 \\
(.68)\end{array}$ \\
\hline ER & $.27^{* *}$ & 1.0 & & & & & & .761 & $\begin{array}{c}2.78 \\
(1.42)\end{array}$ & $\begin{array}{c}2.63 \\
(1.23)\end{array}$ & $\begin{array}{c}2.61 \\
(1.29)\end{array}$ & $\begin{array}{l}2.03 \\
(.85)\end{array}$ \\
\hline INR & $-.29 * *$ & .12 & 1.0 & & & & & .878 & $\begin{array}{l}4.67 \\
(1.58)\end{array}$ & $\begin{array}{c}3.99 \\
(1.67)\end{array}$ & $\begin{array}{c}5.06 \\
(1.46)\end{array}$ & $\begin{array}{l}5.15 \\
(1.51)\end{array}$ \\
\hline IDR & $-.57^{* *}$ & $-.26 * *$ & $.39 * *$ & 1.0 & & & & .756 & $\begin{array}{c}5.76 \\
(1.01)\end{array}$ & $\begin{array}{l}5.97 \\
(.95)\end{array}$ & $\begin{array}{l}6.06 \\
(.73)\end{array}$ & $\begin{array}{l}6.14 \\
(.66)\end{array}$ \\
\hline IM & $-52 * *$ & $-.33 * *$ & $.15 *$ & $.70 * *$ & 1.0 & & & .910 & $\begin{array}{c}5.58 \\
(1.16)\end{array}$ & $\begin{array}{c}6.06 \\
(1.09)\end{array}$ & $\begin{array}{c}5.83 \\
(1.08)\end{array}$ & $\begin{array}{l}6.05 \\
(0.73)\end{array}$ \\
\hline $\mathrm{COM}$ & $-.49 * *$ & $-.29 * *$ & .12 & $.62 * *$ & $.76^{* *}$ & 1.0 & & .892 & $\begin{array}{c}5.13 \\
(1.25)\end{array}$ & $\begin{array}{c}5.47 \\
(1.28)\end{array}$ & $\begin{array}{c}5.43 \\
(1.10)\end{array}$ & $\begin{array}{r}5.76 \\
(0.79)\end{array}$ \\
\hline \multirow[t]{2}{*}{ PA } & -.12 & .06 & .06 & $.23 * *$ & $.22 * *$ & $.15^{*}$ & 1.0 & .687 & $\begin{array}{c}40.44 \\
(35.39)\end{array}$ & $\begin{array}{c}48.64 \\
(33.64)\end{array}$ & $\begin{array}{c}36.44 \\
(26.23)\end{array}$ & $\begin{array}{r}36.53 \\
(25.88)\end{array}$ \\
\hline & & & & & & & & & \multicolumn{2}{|c|}{$\begin{array}{c}\mathrm{M}_{\mathrm{age}}=18.19 \\
\mathrm{SD}=.65\end{array}$} & \multicolumn{2}{|c|}{$\begin{array}{c}\mathrm{M}_{\mathrm{age}}=18.10 \\
\mathrm{SD}=.79\end{array}$} \\
\hline
\end{tabular}

Note. ** $\mathrm{p}<.01 ;{ }^{*} \mathrm{p}<.05 ; \mathrm{AM}=$ Amotivation; $\mathrm{ER}=$ Extrinsic Regulation; INR = Introject Regulation; IDR = Identified Regulation; IM = Intrinsic Motivation; Com = Competence; $\mathrm{PA}=$ Weekly exercise METs; $\mathrm{M}=$ Mean; $\mathrm{SD}=$ Standard Deviation; $\mathrm{a}=$ Cronbach's alpha. 


\section{Primary analysis}

Prior to conducting the primary analysis, age and gender were checked against the multivariate constellation of dependent variables. In this analysis, neither age or gender was significantly associated with the multivariate constellation of dependent variables, Wilks' Lambda $=.94, \mathrm{~F}(7,189)=1.82, \mathrm{p}=.084, \eta^{2}=.06$ for age, and Wilks' Lambda $=.96, \mathrm{~F}(7,189)=1.24, \mathrm{p}=.285, \eta^{2}=.04$ for gender. As neither was significant, they were not controlled for in the main analysis.

The one-way (required vs. elective) MANOVA yielded a significant main effect for PAE policy, Wilks' Lambda = $.90, \mathrm{~F}(7,191)=3.21, \mathrm{p}<.01, \eta^{2}=.11$. The follow up ANOVAs for the PAE policy revealed differences in amotivation, $\mathrm{F}(1,197)=4.57, \mathrm{p}<.05, \eta^{2}=.02$, introjected regulation, $\mathrm{F}(1,197)=10.24, \mathrm{p}<.01, \eta^{2}=.05$, identified regulation, $\mathrm{F}(1,197)=6.77, \mathrm{p}<.05, \eta^{2}=.03$, and competence, $\mathrm{F}(1,197)=4.83, \mathrm{p}<.05, \eta^{2}=.02$. However, the following variables were unrelated to PAE policy, intrinsic motivation, $\mathrm{F}(1,197)=1.42, \mathrm{p}=.23, \eta^{2}=.007$, extrinsic regulation, $\mathrm{F}(1,197)=1.49, \mathrm{p}=.22, \eta^{2}=.008$, and physical activity levels, $\mathrm{F}(1,197)=3.10, \mathrm{p}=.08, \eta^{2}=.01$.

With regard to the student's enrolment in C/UIPAP, under the required policy, the most commonly enrolled-in classes were team sports (27.8\%) and mind-body (24.8\%), whereas under the elective arrangement they were fitness (38.2\%) and mind-body (28.9\%). As summarized in Table 2, the predictors of students' enrolment in team sports (e.g., basketball, frisbee, soccer) classes included having a required PAE policy (OR $=5.42,95 \%$ CI [2.24, $13.12])$, identified regulation ( $\mathrm{OR}=0.35,95 \% \mathrm{CI}[0.16,0.78]$ ), and competence ( $\mathrm{OR}=2.27,95 \% \mathrm{CI}[1.15,4.47])$. The predictors of enrolment in mind-body (e.g., Pilates, yoga) classes included gender ( $\mathrm{OR}=6.50,95 \% \mathrm{CI}[2.01$, $21.02])$, amotivation $(\mathrm{OR}=2.08,95 \% \mathrm{CI}[1.21,3.56])$, and competence $(\mathrm{OR}=0.46,95 \% \mathrm{CI}[0.29,0.74])$. The predictors of enrolment in fitness classes (e.g., aerobics, conditioning, running) included having an elective PAE policy (OR=0.53 95\% CI $[0.28,0.99])$ and the participants' weekly MET scores (OR $=1.01,95 \% \mathrm{CI}[1.00,1.02])$.

\begin{tabular}{|c|c|c|c|c|c|c|c|c|c|}
\hline \multirow{2}{*}{ Variables } & \multicolumn{3}{|c|}{ Team sports } & \multicolumn{3}{|c|}{ Mind body } & \multicolumn{3}{|c|}{ Fitness } \\
\hline & $\begin{array}{c}\text { B } \\
\text { (SE) }\end{array}$ & OR & $\begin{array}{c}\mathbf{p} \\
\text { value }\end{array}$ & $\begin{array}{c}\text { B } \\
\text { (SE) }\end{array}$ & OR & $\begin{array}{c}\mathbf{p} \\
\text { value }\end{array}$ & $\begin{array}{l}\text { B } \\
\text { (SE) }\end{array}$ & OR & $\begin{array}{c}\mathbf{p} \\
\text { value }\end{array}$ \\
\hline AM & $\begin{array}{l}-.77 \\
(.45)\end{array}$ & 0.46 & .086 & $\begin{array}{c}.73 \\
(.28)\end{array}$ & 2.08 & 0.08 & $\begin{array}{l}-.44 \\
(.28)\end{array}$ & 0.65 & .123 \\
\hline ER & $\begin{array}{l}.19 \\
(.17)\end{array}$ & 1.20 & .263 & $\begin{array}{l}-.03 \\
(.14)\end{array}$ & 0.97 & .808 & $\begin{array}{l}-.04 \\
(.13)\end{array}$ & 0.89 & .326 \\
\hline INR & $\begin{array}{l}-.20 \\
(.15)\end{array}$ & 0.82 & .179 & $\begin{array}{l}.00 \\
(.13)\end{array}$ & 1.00 & .997 & $\begin{array}{c}.07 \\
(.12)\end{array}$ & 1.07 & .562 \\
\hline IDR & $\begin{array}{c}-1.04 \\
(.40)\end{array}$ & 0.35 & .010 & $\begin{array}{c}.55 \\
(.33)\end{array}$ & 1.74 & .091 & $\begin{array}{c}.05 \\
(.29)\end{array}$ & 1.05 & .867 \\
\hline IM & $\begin{array}{l}.67 \\
(.42)\end{array}$ & 1.95 & .109 & $\begin{array}{c}.46 \\
(.26)\end{array}$ & 1.58 & .085 & $\begin{array}{l}-.42 \\
(.25)\end{array}$ & 0.66 & .094 \\
\hline Com & $\begin{array}{c}.82 \\
(.35)\end{array}$ & 2.27 & .018 & $\begin{array}{l}-.78 \\
(.24)\end{array}$ & 0.46 & .001 & $\begin{array}{l}.16 \\
(.22)\end{array}$ & 1.17 & .472 \\
\hline PA & $\begin{array}{l}-.01 \\
(.01)\end{array}$ & 0.99 & .354 & $\begin{array}{l}.01 \\
(.01)\end{array}$ & 1.01 & .286 & $\begin{array}{c}.01 \\
(.005)\end{array}$ & 1.01 & .037 \\
\hline $\begin{array}{l}\text { PAE policy } \\
\text { (Required) }\end{array}$ & $\begin{array}{l}1.69 \\
(.45)\end{array}$ & 5.42 & .000 & $\begin{array}{l}-.52 \\
(.36)\end{array}$ & 0.60 & .153 & $\begin{array}{l}-.64 \\
(.33)\end{array}$ & 0.53 & .048 \\
\hline $\begin{array}{l}\text { Gender } \\
\text { (Female) }\end{array}$ & $\begin{array}{l}-.29 \\
(.48)\end{array}$ & 0.75 & .545 & $\begin{array}{l}1.88 \\
(.60)\end{array}$ & 6.50 & 0.02 & $\begin{array}{l}-.20 \\
(.38)\end{array}$ & 0.82 & .592 \\
\hline Model fit & \multicolumn{3}{|c|}{$\begin{array}{c}\mathrm{x}^{2}(9)=46.976 \\
\mathrm{p}<.001\end{array}$} & \multicolumn{3}{|c|}{$\begin{aligned} x^{2}(9) & =35.631 \\
p & <.001\end{aligned}$} & \multicolumn{3}{|c|}{$\begin{array}{c}x^{2}(9)=15.662 \\
p=.074\end{array}$} \\
\hline
\end{tabular}

Note. $A M=$ Amotivation; ER = Extrinsic Regulation; INR = Introject Regulation; IDR = Identified Regulation; IM = Intrinsic Motivation; Com = Competence; PA = Weekly exercise METs.

\section{Discussion}

Participants enrolled at the university that required them to experience PAE in order to graduate exhibited lower levels of motivation in comparison to those enrolled at the university where PAE was an elective. Amotivation is characterized by a low state of perceived competence and/or not valuing an activity or its potential outcomes. While values and outcomes were not directly assessed in the present study, competence was. In this analysis, the direct bivariate relationship between amotivation and competence was inverse. Higher degrees of competence were also found to be associated with enrolment in team sport- and mind-body-type PAE courses (i.e., those with higher levels of skills tended to enrol).

Similarly, one possible indirect indicator of valuing an activity and/or its potential outcomes is to actually participate in the activity. In the present study, the direct bivariate relationship between amotivation and weekly physical activity participation was also inverse. The direction of this relationship is suggestive of an amotivated state. The study participants' who engaged in the most physical activity during the previous week were also most likely to be enrolled in a fitness-type PAE course.

Of course, amotivation, competence, and physical activity behaviours are all states. That is, unlike traits, which are relatively permanent and stable, states have the possibility of being changed. A quality PAE experience during the impressionable early adult years has the potential to establish long-term physical activity habits (Adams \& 
Brynteson, 1992; Brynteson \& Adams, 1993; Casebolt et al., 2017; Pearman et al., 1997; Sparling \& Snow, 2002). As service delivery programmes within academic units; however, C/UIPAP are often taught by novice teachers with very little guidance, preparation, or supervision (Cardinal, 2017; Russell, 2011). Those teaching C/UIPAP courses may also have various degrees of real or perceived role-conflict associated with their other assigned duties, obligations, and responsibilities (Beaudoin et al., 2018; Cardinal, 2017; Hensley, 2000). Obviously a situation in which students enter a course in an amotivated state and who encounter an instructor who may be less than fully committed or prepared is undesirable.

Similar to what has been observed to occur in K-12 settings (Cardinal, Yan, \& Cardinal, 2013; Ladwig, Vazou, \& Ekkekakis, 2018), a bad PAE experience as a college or university student is unlikely to foster a positive shift in the students' psychological state. As such, efforts aimed at avoiding the possible scenarios described above and improving instruction within C/UIPAP courses have occurred (Beaudoin et al., 2018; Brock, Russell, Cosgrove, \& Richards, 2018; Kim, Cardinal, \& Cardinal, 2015; Kim, Cardinal, \& Yun, 2015; National Association for Sport and Physical Education, 2009; Russell, 2011; Russell, Wadsworth, Hastie, Rudisill, 2014; Stapleton, Taliaferro, \& Bulger, 2017). More efforts like this are needed, particularly if students are being required to take PAE in order to earn a baccalaureate degree. Quality instructors are able to adapt and modify their teaching methodologies and approaches to best match the collective and individual interests, needs, and skill-levels of their students (Beaudoin et al., 2018). Moreover, C/UIPAP programme administrators and PAE course instructors must focus on eliminating negative experiences, fostering positive experiences, and minimizing embarrassment by promoting enjoyment and inclusion and creating an environment of optimal challenge and social support.

Under the required policy arrangement, PAE courses reach all students, including those who might not otherwise be motivated to participate in elective PAE courses (Kim \& Cardinal, 2018). In contrast, elective PAE courses are the most respectful of students' educational autonomy (Hensley, 2000; Issues, 2009, 2018; Kim \& Cardinal, 2016). Self-determination theory (Deci \& Ryan, 2000) posits that an individuals' intrinsic motivation for being physical activity is at least partially related to their having a choice in the matter. Being required to take a course may be met with resistance (Corbin \& Cardinal, 2008). As such, and to at least partially account for this, C/ UIPAPs, even when required, can be structured in a way that allows for individual student choice, options, and variety (e.g., choice of class/classes, format of class/classes (i.e., activity-based, lecture/lab-based), grading structure (e.g., Pass/Fail versus letter grade), scheduling/timing).

In considering the findings of this study, several limitations should be kept in mind. First, as a cross-sectional study, causal inference is not implied and should not be assumed. Second, the participating universities were selected on the basis of their different PAE policies and their geographic proximity to one another. Third, the study participants self-selected into the study; as such, our sample was one of convenience. Lastly, the data were obtained by self-report; therefore, item interpretation, recall, and/or social desirability may have affected the participants' responses in an undermining manner.

With only half of college/university students engaging in physical activity on a regular basis (ACHA, 2018), there is an urgent need to address this problem. In the mid-19th century, a compulsory PAE programme debuted in higher education for the expressed need of addressing the generally poor state of health of students at Amherst College (Cardinal et al., 2012). Other institutions followed suit and began offering compulsory PAE programmes. However, required PAE courses have declined in the 21st century in comparison to the 20th century. In studies of college alumni, those who report having taken PAE courses while in college/university report higher levels of physical activity in adulthood in comparison to those who did not (Adams \& Brynteson, 1992; Brynteson \& Adams, 1993; Casebolt et al., 2017; Pearman et al., 1997; Sparling \& Snow, 2002). It is not entirely clear, though, whether the alumni in those studies were required to take PAE or whether they elected to take PAE.

On the basis of the present study as well as one past study (Kim \& Cardinal, 2018), when PAE courses are offered on an elective basis, the most competent, motivated, and physically active students tend to enrol. In other words, the programmes are most likely catering to an audience that would likely be physically active without any such coursework vis-à-vis campus or community-based physical activity and recreational opportunities; some of which may not be fully inclusive environments and/or structured in an educational manner (Cardinal \& Spaziani, 2003; Hoang, Cardinal, Newhart, 2016). On the other hand, when quality PAE courses are required of students, all students can benefit. The information obtained in this study might contribute to better informed C/ UIPAP advocacy and programming efforts.

\section{REFERENCES}

Adams, T., \& Brynteson, P. (1992). A comparison of attitudes and exercise habits of alumni from colleges with varying degrees of physical education activity programs. Research Quarterly for Exercise and Sport, 63(2), 148-152. doi: 10.1080/02701367.1992.10607575

American College Health Association. (2018). American College Health Association-National college health assessment II: Reference group executive summary Fall 2017. Hanover, MD: American College Health Association.

Ansuini, C.G. (2001). The impact of terminating a wellness/activity requirement on campus trends in health and wellness [Abstract]. American Journal of Health Promotion, 15, 455.

Bandura, A. (1986). Social foundations of thought and action: A social cognitive theory. Englewood Cliffs, NJ: Prentice-Hall. 
Barney, D., Pleban, F. T., Wilkinson, C., \& Prusak, K. A. (2015). Identifying high school physical education physical activity patterns after high school. The Physical Educator, 72(2). 278-293.

Blackwell, D. L., \& Clarke, T. C. (2018). State variation in meeting the 2008 federal guidelines for both aerobic and muscle-strengthening activities through leisure-time physical activity among adults aged 18-64: United States 2010-2015. National Health Statistics Reports; no 112. Hyattsville, MD: National Center for Health Statistics.

Brock, S. J., Russell, J. A., Cosgrove, B., \& Richards, J. (2018). Administrative strategies for delivering high-quality instruction in a university-based physical activity and wellness program. Kinesiology Review. doi: https://doi.org/10.1123/kr.2018-0040

Beaudoin, C., Parker, T., Tiemersma, K., \& Lewis, C. (2018). Evaluating university physical activity courses from student and instructor perspectives. Journal of Physical Education, Recreation and Dance, 89(1), 7-11. doi: 10.1080/07303084.2017.1390508

Brynteson, P., \& Adams, T. (1993). The effects of conceptually based physical education programs on attitude and exercise habits of college alumni after 2 to 11 years of follow-up. Research Quarterly for Exercise and Sport, 64(2), 208-212. doi: 10.1080/02701367.1993.10608798

Cardinal, B. J. (2016). Physical activity education's contributions to public health and interdisciplinary studies: Documenting more than individual health benefits [Editorial]. Journal of Physical Education, Recreation and Dance, 87(4), 3-5. doi: 10.1080/07303084.2016.1142182

Cardinal, B. J. (2017). Quality college and university instructional physical activity programs contribute to mens sana in corpore sano, "the good life," and healthy societies. Quest, 69(4), 531-541. doi: 10.1080/00336297.2017.1320295

Cardinal, B. J., Sorensen, S. D., \& Cardinal, M. K. (2012). Historical perspective and current status of the physical education graduation requirement at American 4-year colleges and universities. Research Quarterly for Exercise and Sport, 83, 503-512. doi: 10.1080/02701367.2012.10599139

Cardinal, B. J., \& Spaziani, M. D. (2003). ADA compliance and the accessibility of physical activity facilities in western Oregon. American Journal of Health Promotion, 17, 197-201. doi: https://doi.org/10.4278/08901171-17.3.197

Cardinal, B. J., Yan, Z., \& Cardinal, M. K. (2013). Negative experiences in physical education and sport: How much do they affect physical activity participation later in life? Journal of Physical Education, Recreation and Dance, 84(3), 49-53. doi: 10.1080/07303084.2013.767736

Casebolt, K., Chiang, L-M., Melton, B., \& Russell, J. (2017). College/university instructional physical activity programs and academic success in higher education. International Journal of Kinesiology in Higher Education, 1(3),100-106. doi: 10.1080/24711616.2017.1328196

Corbin, C. B., \& Cardinal, B. J. (2008). Conceptual physical education: The anatomy of an innovation. Quest, 60, 467-487. doi: 10.1080/00336297.2008.10483593

Center for Disease Control and Prevention. (2016). Youth risk behavior surveillance -United States, 2015. Morbidity and Mortality Weekly Report: Surveillance Summaries, 63(4). 1-168. doi: 10.15585/mmwr. ss6506al

Curry, J., Jenkins, J. M., \& Weatherford, J. (2015). Focus on freshman: Basic instruction programs enhancing physical activity. The Physical Educator, 72(4), 621-639.

Deci, E. L., \& Ryan, R. M. (2000). The "what" and" why" of goal pursuits: Human needs and the self-determination of behavior. Psychological Inquiry, 11, 227-268. doi:10.1207/S15327965PLI1104_01

Doerksen, S. E., Umstattd, M. R., \& McAuley, E. (2009). Social cognitive determinants of moderate and vigorous physical activity in college freshmen. Journal of Applied Social Psychology, 39(5), 1201-1213. doi: $10.1111 /$ j.1559-1816.2009.00478.x

Gill, D. L. (2009). 2008 C. H. McCloy Lecture. Social psychology and physical activity. Research Quarterly for Exercise and Sport, 80, 685-695. doi: 10.1080/02701367.2009.10599609

Godin, G., \& Shephard, R. J. (1985). A simple method to assess exercise behavior in the community. Canadian Journal of Applied Sport Sciences, 10(3), 141-146.

Hensley, L. D. (2000). Current status of basic instruction program in physical education at American colleges and universities. Journal of Physical Education, Recreation and Dance, 71(9), 30-36. doi: 10.1080/07303084.2000.10605719

Hoang, T. V., Cardinal B. J., \& Newhart, D. W. (2016). An exploratory study of ethnic minority students' constraints to and facilitators of engaging in campus recreation. Recreational Sports Journal, 40(1), 69-81. doi: http://dx.doi.org/10.1123/rsj.2014-0051

Issues. (2009). Should universities require all students to pass a physical activity course? Journal of Physical Education, Recreation and Dance, 80(4), 8-11. doi: 10.1080/07303084.2009.10598303

Issues. (2018). Why is it important to have general physical education courses in higher education? Journal of Physical Education, Recreation and Dance, 89(6), 71-72. doi: 10.1080/07303084.2018.1478573

Kilpatrick, M., Hebert, E., \& Bartholomew, J. (2005). College students' motivation for physical activity: Differentiating men's and women's motives for sport participation and exercise. Journal of American College Health, 54(2), 87-94. doi: 10.3200/JACH.54.2.87-94

Kim, M., \& Cardinal, B. J. (2016). A review of how physical activity education policies in higher education affect college students' physical activity behavior and motivation. International Journal of Human Movement Science, 10(2), 41-51. 
Kim, M., \& Cardinal, B. J. (2017). Why do university students enroll in physical activity education courses? Differential affects of required versus elective institutional policies. International Journal of Sports and Physical Education, 3(3), 16-26. doi: http://dx.doi.org/10.20431/2454-6380.0303003

Kim, M., \& Cardinal, B. J. (2018). Differences in university students' motivation between a required and an elective physical activity education policy. Journal of American College Health. doi: 10.1080/07448481.2018.1469501

Kim, M., Cardinal, B. J., \& Cardinal, M. K. (2015). Diversifying physical activity course curricula to meet institutional expectations and satisfy student needs in higher education: An introductory framework. Journal of Physical Education, Recreation and Dance, 86(9), 5-8. doi: 10.1080/07303084.2015.1086608

Kim, M., Cardinal, B. J., \& Yun, J. (2015). Enhancing student motivation in college and university physical activity courses using instructional alignment practices. Journal of Physical Education, Recreation and Dance, 86(9), 33-38. doi: 10.1080/07303084.2015.1085343

Ladwig, M. A., Vazou, S., \& Ekkekakis, P. (2018). "My best memory is when I was done with it”: PE memories are associated with adult sedentary behavior. Translational Journal of the ACSM, 3(16), 119-129. doi: 10.1249/TJX.0000000000000067

Lackman, J., Smith, M. L., \& McNeill, E. B. (2015). Freshman college students' reasons for enrolling in and anticipated benefits from a basic college physical education activity course. Frontiers in Public Health, 3 (Article \#162), 1-11. doi: 10.3389/fpubh.2015.00162

Leenders, N. Y., Sherman, W. M., \& Ward, P. (2003). College physical activity courses: Why do students enroll, and what are their health behaviors? Research Quarterly for Exercise and Sport, 74(3), 313-318. doi: 10.1080/02701367.2003.10609096

Lewin, K. (1936). A dynamic theory of personality. New York: McGraw Hill.

Li, K. K., Cardinal, B. J., \& Settersten, R. A. (2009). A life-course perspective on physical activity promotion: Application and implication. Quest, 61(3), 336-352. doi: 10.1080/0036297.2009.10483620

Mak, J. Y., \& Cheung, S. Y. (2018). The challenge of physical activity courses in higher education. Journal of Physical Education, Recreation and Dance, 89(6), 7-8. doi: 10.1080/07303084.2018.1478555

Markland, D., \& Tobin, V. (2004). A modification to the Behavioral Regulation in Exercise Questionnaire to include assessment of amotivation. Journal of Sport and Exercise Psychology, 26(2), 191-196.

McAuley, E., Duncan, T., \& Tammen, V. V. (1989). Psychometric properties of the Intrinsic Motivation Inventory in a competitive sport setting: A confirmatory factor analysis. Research Quarterly for Exercise and Sport, 60(1), 48-58. doi: 10.1080/02701367.1989.10607413

National Association for Sport and Physical Education. (2009). Appropriate instructional practice guidelines for higher education physical activity programs: A position statement from the National Association for Sport and Physical Education (2nd Ed.). Reston, VA: Author. Available at: https://rmpe.appstate.edu/sites/ rmpe.appstate.edu/files/naspe_app_pract_gdlns_hepap.pdf

Pearman, S. N., Valois, R. F., Sargent, R. G., Saunders, R. P., Drane, J. W., \& Macera, C. A. (1997). The impact of a required college health and physical education course on the health status of alumni. Journal of American College Health, 46(2), 77-85. doi: 10.1080/07448489709595591

Russell, J. A. (2011). Graduate teaching-assistant development in college and university instructional physical activity programs. Journal of Physical Education, Recreation and Dance, 82(4), 22-32. doi: 10.1080/07303084.2011.10598610

Russell, J., Wadsworth, D., Hastie, P., \& Rudisill, M. (2014). Incorporating e-learning to enhance instruction and student experiences in collegiate physical activity courses. Kinesiology Review, 3, 247-252. doi: http:// dx.doi.org/10.1123/kr.2014-0066

Sallis, J. F. (2018). Needs and challenges related to multilevel interventions: Physical activity examples. Health Education and Behavior, 45, 661-667. doi: https://doi.org/10.1177/1090198118796458

Sallis, J. F., Calfas, K. J., Nichols, J. F., Sarkin, J. A., Johnson, M. F., Caparosa, S.,... Alcaraz, J. E. (1999). Evaluation of a university course to promote physical activity: Project GRAD. Research Quarterly for Exercise and Sport, 70, 1-10. doi: 10.1080/02701367.1999.10607725

Sargent, D. A. (1908). Physical training in school and college shall it be compulsory? American Physical Education Review, 13(1), 1-13. doi: https://doi.org/10.1080/23267224.1908.10650051

Sparling, P. B. (2003). College physical education: An unrecognized agent of change in combating inactivity-related diseases. Perspectives in Biology and Medicine, 46, 579-87.

Sparling, P. B., \& Snow, T. K. (2002). Physical activity patterns in recent college alumni. Research Quarterly for Exercise and Sport, 73(2), 200-205. doi: 10.1080/02701367.2002.10609009

Stapleton, D. T., Taliaferro, A. R., \& Bulger, S. M. (2017). Teaching an old dog new tricks: Past, present, and future priorities for higher education physical activity programs. Quest, 69, 401-418. doi:10.1080/00336 297.2016.1256825

Stokols, D. (1992). Establishing and maintaining healthy environments: toward a social ecology of health promotion. American Psychologist, 47(1), 6-22.

U.S. Department of Health and Human Services. (2008). Office of Disease Prevention and Health Promotion. Healthy People 2020. Washington, DC. Available at http://www.healthypeople.gov/2020/topics-objectives/topic/physical-activity/objectives. Accessed April 21, 2015.

Weinfeldt, J. A, \& Visek, A. J. (2009). Why college students enroll in exercise and sport activity classes: An exploratory investigation. Missouri Journal of Health, Physical Education, Recreation and Dance, 19, 64-76. 
Williams, S. E., Greene, J. L., Fry, A., Neuberger, J., \& Satinsky, S. (2018). A study of conceptually based physical education in higher education. The Physical Educator, 75, 471-497. doi: 10.18666/TPE-2018V75-I3-7929

Woekel, E., Ebbeck, V., Concepcion, R. Y., Readdy, T., Li, K.-K., Lee, H., \& Cardinal, B. J. (2013). Physical activity, nutrition, and self-perception changes related to a university "Lifetime Fitness for Health" curriculum. The Physical Educator, 70(4), 374-393.

Yan, Z., \& Cardinal, B. J. (2013). Promoting physical activity among international students in higher education: A peer education approach. Journal of Physical Education, Recreation and Dance, 84(1), 35-40. doi: $10.1080 / 07303084.2013 .746151$

You, J., Craig, C. J. \& Oh, S. (2018): Challenges in the new roles of physical education as liberal education in higher education. Quest. doi: 10.1080/00336297.2018.1498794

Zick, C. D., Smith, K. R., Brown, B. B., Fan, J. X., \& Kowaleski-Jones, L. (2007). Physical activity during the transition from adolescence to adulthood. Journal of Physical Activity and Health, 4(2), 125-137. 